University of Nebraska - Lincoln

DigitalCommons@University of Nebraska - Lincoln

2004

The 2002 Downturn in State Revenues: A Comparative Review and Analysis

J. Fred Giertz

University of Illinois at Urbana-Champaign, jgiertz@illinois.edu

Seth H. Giertz

University of Nebraska-Lincoln, sgiertz2@unl.edu

Follow this and additional works at: https://digitalcommons.unl.edu/econfacpub

Part of the Economics Commons

Giertz, J. Fred and Giertz, Seth H., "The 2002 Downturn in State Revenues: A Comparative Review and Analysis" (2004). Economics Department Faculty Publications. 56.

https://digitalcommons.unl.edu/econfacpub/56

This Article is brought to you for free and open access by the Economics Department at DigitalCommons@University of Nebraska - Lincoln. It has been accepted for inclusion in Economics Department Faculty Publications by an authorized administrator of DigitalCommons@University of Nebraska - Lincoln. 


\section{The 2002 Downturn in State Revenues: A Comparative Review and Analysis}

\section{J. Fred Giertz \\ Institute of Government and Public Affairs and Department of Economics, University of Illinois at Urbana- Champaign, Urbana, IL 61801}

\section{Seth H. Giertz} Congressional Budget Office, Washington, D.C. 20515

\section{National Tax Journal} Vol. LVII, No. 1 March 2004

\begin{abstract}
We analyze the behavior of state revenues since the early 1950s to determine the severity of the revenue declines experienced by states after the 2001 recession. Both total state revenues for the nation and state-level data for each state are studied. We conclude that the states were indeed hit with an unprecedented downturn in revenues-unlike anything that had been experienced in the preceding half-century. Further and contrary to general perceptions, revenue increases in the years preceding the downturn were not particularly strong compared to revenue increases in the years leading up to previous recessions. We further conclude that most proposed budget rules dealing with either taxes, spending, or savings would have been insufficient to address the states' problems and that states will need major discretionary structural changes in state revenues and expenditures to return to fiscal balance.
\end{abstract}

\section{INTRODUCTION}

Ts the state budget crisis that had its origins in the ecoInomic expansion of the late 1990s and the recession that began in 2001 sui generis or simply a variant of recent state budget cycles? This is a key issue in assessing blame, if any, for the state budget crises and in planning to improve state decisionmaking. The most important issue is whether appropriate budget rules could have eliminated or at least ameliorated much of the pain that states suffered from the economic downturn.

In its impact on state revenues and in the disconnect with economic conditions, the current state budget cycle of expanding revenues followed by precipitous declines may be a one-of-a-kind phenomenon, the proverbial hundred year flood or perfect storm, that is extremely unlikely to occur again. Alternatively, the cycle may simply be a different version of past cycles that might have been foreseen and responded to better with fuller understanding.

In this paper, we review and analyze the behavior of state revenues since the early 1950s - a period that includes nine recessions as determined by the National Bureau of Economic Research. In the first section of the paper, we conduct an analysis of aggregate state-level data over the last half century. We follow this section with a detailed analysis of state-level data, spanning the last 25 years, which includes 
the dual recessions of the early 1980s, the 1990 recession associated with the Gulf War, and the recession of 2001 associated with the end of the stock market bubble.

Using the information developed in the first two sections, we develop a stylized simulation examining various policies that a representative state might have undertaken during the expansion to manage its budget in preparation for the economic downturn. We focus on how various proposed automatic or semi-automatic budget rules limiting discretionary tax and spending changes might have mitigated the problems states are currently facing. We conclude with a brief assessment of how well states have managed their fiscal affairs given the magnitude of the downturn and the political constraints that they face.

The aggregate data suggest that the states were indeed hit with an unprecedented downturn in revenues-unlike anything that had been experienced in the preceding half-century. Further and contrary to general perceptions, revenue increases in the years preceding the downturn were not particularly strong compared to revenue increases in the years leading up to previous recessions. Not surprisingly, all states were not impacted in the same way during the recent recession nor was it the worst recent downturn for all states. For some states, the dual recessions of the early 1980s were associated with larger revenue declines (as a share of state income). However, relative to the severity of the recession, the underperformance of revenues was most pronounced in fiscal 2002.

Are the states themselves to blame for their current situation? The simulation analysis seems to exonerate the states, suggesting that there was little the states could have done, given reasonable ex- pectations based on past cycles and given political constraints that rule out many responses. Furthermore, no reasonable budget rule could have allowed states to navigate the recent fluctuations on automatic pilot. However, this does not excuse what appears to be the slow, temporizing response of most states once the magnitude of the problems became apparent (see Maag and Merriman (2003)).

\section{DATA AND DEFINITIONS}

In this paper, we focus on own-source general tax revenues. This is the largest component of state revenue and has been relatively stable at around 76 percent of total own-source revenue over the last decade. ${ }^{1}$ And, unlike other state budget data, state tax revenue is available for fiscal 2003. This provides one and sometimes two additional years of crucial data for the states compared to other revenue and expenditure information. The use of tax revenues focuses on the most important and most cyclically-sensitive component of state finance. We do not provide here a full treatment of the state budget process through an examination of both expenditures and revenues. ${ }^{2}$ However, the analysis of revenues makes it possible to evaluate options for both revenue enhancements and/or expenditure cuts that would help bring the budgets into balance. The focus on revenue changes highlights the magnitude of the problems states face, but it does not shed much light on the resources states have to deal with these problems or the manner in which the problems are resolved. At this stage, most states have yet to resolve these issues fully.

A number of studies assessing the impact of the recent recessions on state finances use combined state and local revenues (see Knight, Kusko, and Ru-

\footnotetext{
1 The coefficient of correlation between tax revenue and total revenue is .984 for this period.

2 The analysis is largely descriptive and is not based on a formal model of the budget behavior of the states such as Poterba (1994).
} 
bin (2003), Garret (2003), Daly (2003), and The Wall Street Journal (2003)). The performance of combined state and local revenues often does not provide a good picture of either state or local revenues because considerable differences exist between the behavior of these revenues. In particular, local government revenue performed much better during the recent downturn because of local governments' reliance on the property tax. Property tax revenues, the almost exclusive province of local governments, increased during the economic downturn because of the stability of the assessment base as well as rate increases. Property taxes in fiscal years 2000, 2001, 2002, and 2003 increased $4.5,5.3,10.2$ and 1.3 percent respectively. The Wall Street Journal (2003), for example, recently noted that, "state and local receipts have been rising smartly for the past six quarters, reaching a new quarterly record.... ." It uses this evidence to argue that state governments are in a strong fiscal position, and further asserts that complaints over state governments' poor fiscal health are merely disingenuous attempts by those looking for an excuse to raise taxes.

The term general revenues as used here is a Census Bureau classification that includes all state government activity except state-run liquor stores, utilities, and insurance trusts. This is a more comprehensive category than the commonly-used general fund budget designation. In a typical fund accounting framework used in most states, general fund activities include most core state activities, but exclude major functional areas, such as transportation, which are segregated in non-general fund accounts such as the road fund. Therefore, the Census numbers used here do not correspond exactly to the numbers reported in most state budgets and in the press nor do they relate precisely to the revenues used in calculations of state budget deficits or shortfalls. However, the data used here are highly correlated with the other measures and they are collected using a consistent classification system that is applied to all states.

Because of its inclusiveness, the general revenue category used in this analysis is likely to be somewhat more stable than typical general fund revenues since it includes motor fuel taxes and other excise taxes. Motor fuel taxes are often levied on a unit basis and do not vary as much during the business cycle as income tax and sales tax receipts.

To deal with population and price changes over the time period, tax revenues are measured in per capita, real (fiscal 2003) dollars. Revenues combine both the impacts of the economy and of discretionary changes in tax structures. In the last ten years, discretionary changes have had relatively little impact on state revenues. ${ }^{3}$

\section{AGGREGATE RESULTS: FIFTY YEARS OF STATE REVENUES}

\section{Descriptive Analysis}

We now compare the behavior of state tax revenues before, during, and after the recession of 2001 with other downturns over the last 50 years. This is done descriptively with several different charts. Figure 1 depicts state tax revenues as a percentage of GDP from the early 1950s until 2003. ${ }^{4}$ The most striking aspect of this chart in not the cyclical behavior of

\footnotetext{
3 See National Governors Association and National Association of State Budget Officers (2003). Net enacted changes reduced the annual real growth of tax revenues by approximately one percent a year from 1996 to 2001, had virtually no impact in 2002, and increased revenues by 1.5 percent in 2003 . The effects are significantly smaller than the impacts of changes during the 1980s and early 1990s. "Enacted changes" is a term used by National Association of State Budget Officers to disentangle changes generated by the economy and discretionary changes in tax laws.

4 The years referred to throughout this paper regarding revenues and budget issues are fiscal years.
} 
Figure 1. State Taxes as Percentage of GDP

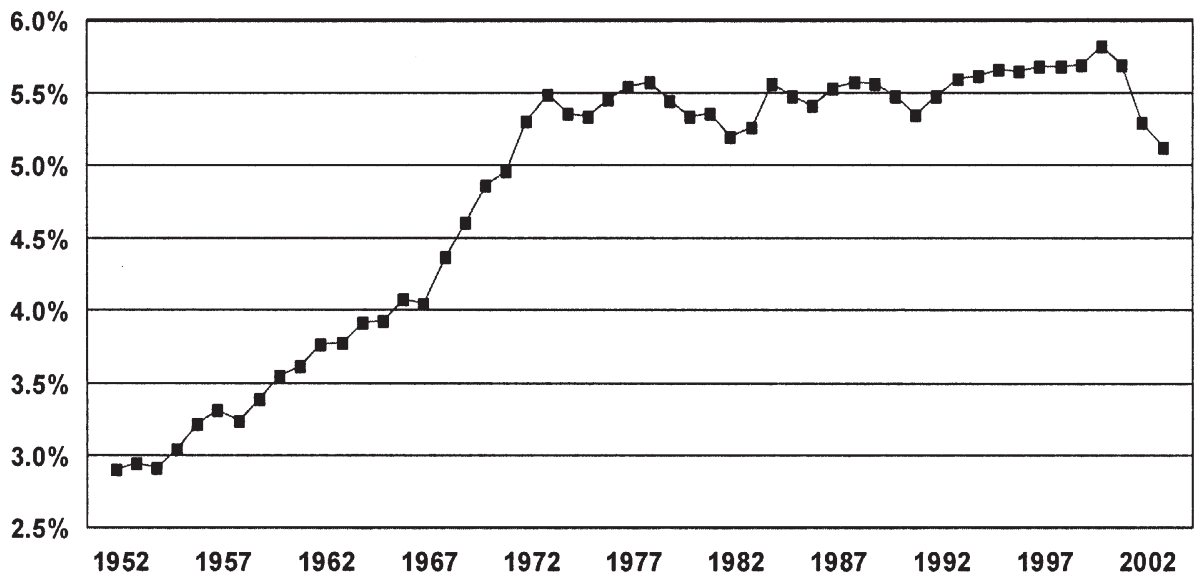

tax revenues, but the marked contrast between the first and the last half of the period. The period before the mid-1970s was one of rapid expansion of state government. States during this period were expanding their activities on a number of fronts, most notably in education. In most states, the financing of primary and secondary education was shifting from local governments (school districts) to the states. Public higher education, which is largely a state function, also expanded rapidly during this period.

This pre-1970 period was also a time of change for state tax systems. States had moved away from the property tax before this period and began to rely more heavily on broad general taxes such as the general sales tax and eventually, the income tax. In 1950, the individual income tax accounted for less than 10 percent of state tax revenues. By 1975, this ratio had increased to about 24 percent. By 2000, the income tax had risen to more than one-third of state tax revenues. These increases were the result of the adoption of the tax by more states and by higher rates imposed with existing taxes.
During the four recessions prior to 1973, the cyclical impacts of recessions on tax revenues were largely swamped by the secular ramping up of state tax burdens. The only declines in the last 30 years were after the 1973, 1980, 1990 and 2001 recessions. The decline after the 2001 recession was by far the greatest with state taxes falling from 5.7 to 5.1 percent of GDP over a two-year period. The other post-1970 declines were much smaller-around one-tenth of one percentage point. With the exception of 2001, the declines were erased in a year or two by natural revenue growth and discretionary increases.

As a percentage of GDP, state taxes rose from 3.0 percent in 1950 to 5.5 percent in 1975. Since 1975, state taxes have hovered around the 5.5 percent level with no significant upward trend. It is interesting to note that the rapid growth of state tax revenues as well as state and local revenues halted several years before the widely publicized tax protest movements such as Proposition 13 in California and Proposition 21/2 in Massachusetts in the late 1970s as well as the "Reagan revolution" of the early 1980s. ${ }^{5}$

\footnotetext{
${ }^{5}$ State and local taxes as a percentage of GDP reached a peak in 1972 and then fell for several years. The 1972 peak was not exceeded until the early 1990s.
} 
Figure 2 confirms the widely publicized statement that the fiscal problems of the states (at least in terms of revenue) are the worst since World War II. ${ }^{6}$ The year 2002 is the only time when revenues fell in current dollar terms. This is the result of a combination of the effects of a steep real revenue decline along with a historically low inflation rate.

In the past, states have considered it a crisis when revenues did not keep pace with inflation. Note in Figure 2 that, prior to 2001, this was a rare occurrence. During the last half of the twentieth century, there were only 5 years when real per capita state tax revenues fell: the recessions of $1958,1974,1981,1982$, and 1991. In these years, the declines were modest: 0.6, 0.9, $0.7,0.7$, and 0.5 percent respectively. Previously, the only back-to-back decline in state revenues occurred during the double dip recessions of the early 1980s. Real revenues actually increased in the recessions of 1953, 1960, and 1969.

Contrast this with the recession of 2001. Here real revenues fell by 7.9 percent for fiscal 2002 followed by another decline on a lower base in 2003 of 1.8 percent. The fiscal 2002 reduction was almost nine times as large as the previous worst performance, while 2003 was twice as large as any pre-2001 decline. The relative size of the 2002 decline was largely the result of the economy. Major tax adjustments are usually not accomplished in the first year of a downturn. The second-year decline in revenue (2003) was the compound effect of a continued downturn along with few states raising taxes to cope with the recession.

Note that the declines for fiscal 2002 and 2003 were in the context of one of the mildest recession on record although the recovery from the recession has been much slower than normal. ${ }^{7}$ It has been suggested that the 2001 recession was a throwback to recessions of the nineteenth century that resulted from vast overinvestment in specific industries (railroads then, telecommunications and information technology now). The decline in asset values and investment, not employment

Figure 2. Annual Changes in Per Capita State Taxes: Nominal and Real

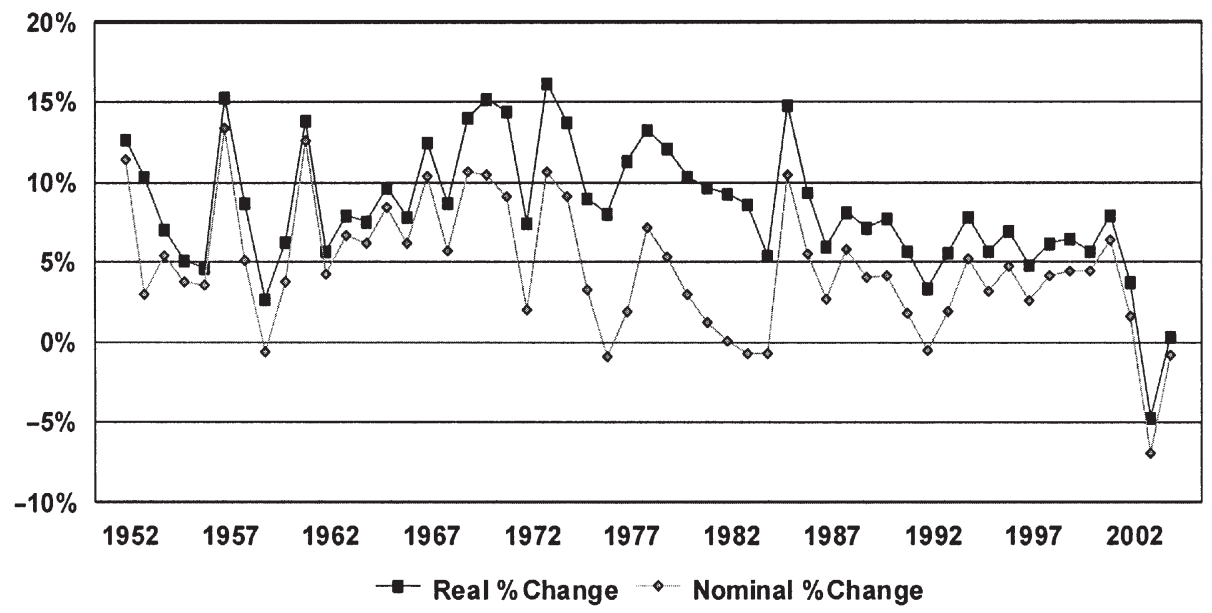

${ }^{6}$ While the data are not included, the results discussed here apply to the period 1945-1951 as well.

A 2003 NBER analysis shows that real GDP, retail sales, and industrial product all declined less steeply in the 2001 recession compared to the average of eight previous recessions, but recovered at a slower rate. (http:// www.nber.org/cycles/hall.pdf) 
and consumption, characterized the recent recession.

It has been alleged that states had an unprecedented run up of revenues in the period before the downturn in fiscal 2002. The combination of a booming economy and an even more vibrant stock market produced revenue windfalls unmatched by past experience. A corollary of this is the assertion that states mismanaged their finances during the boom period instead of taking precautions for the eventual downturn.

We examine this issue in Figure 3 and Table 1. Figure 3 provides information about the two- and four-year cumulative per capita tax revenue increases calculated on a rolling basis from 1953 to 2003. Figure 3 suggests that the years just before the 2001 recession were certainly productive in terms of state revenues, but not out of character with previous pre-recession expansions. The cumulative two- and four-year revenue increase was actually lower than most similar previous periods. This is presented in more detail in Table 1. Here the cumulative four-year pre-recession increase in real per capita state tax
TABLE 1

GROWTH OF STATE TAX REVENUES BEFORE AND AFTER RECENT RECESSIONS

(Real Per Capita)

\begin{tabular}{lcc}
\hline $\begin{array}{l}\text { Recession } \\
\text { (Beginning Quarter) }\end{array}$ & $\begin{array}{c}\text { Previous 4 } \\
\text { Years (\%) }\end{array}$ & $\begin{array}{l}\text { Next 2 } \\
\text { Years (\%) }\end{array}$ \\
\hline July 1953(II) & 20.8 & 3.8 \\
August 1957(III) & 19.3 & -0.5 \\
April 1960(II) & 13.7 & 7.6 \\
December 1969(IV) & 36.2 & 8.9 \\
November 1973(IV) & 28.3 & 0.4 \\
January 1980(I) & 12.9 & -2.7 \\
July 1981(III) & 5.2 & -3.3 \\
July 1990(III) & 12.4 & -1.1 \\
March 2001(I) & 12.5 & -9.6 \\
\hline
\end{tabular}

revenues and the two-year post-recession revenue impacts are presented for the nine post-1950 recessions. Note that the results of the 1981 recession are hard to interpret because that recession occurred before a full recovery took place from the 1980 recession.

Excluding 1981, the four-year revenue increase before 2001 was among the lowest pre-recession periods on record, just barely surpassing the pre-1990 revenue increase. Note also that the two-year postrecession decline after the 2001 recession is by far the most negative on record, nearly three times the next largest percentage

Figure 3. Cumulative 2-Year and 4-Year Changes in Real Per Capita State Taxes

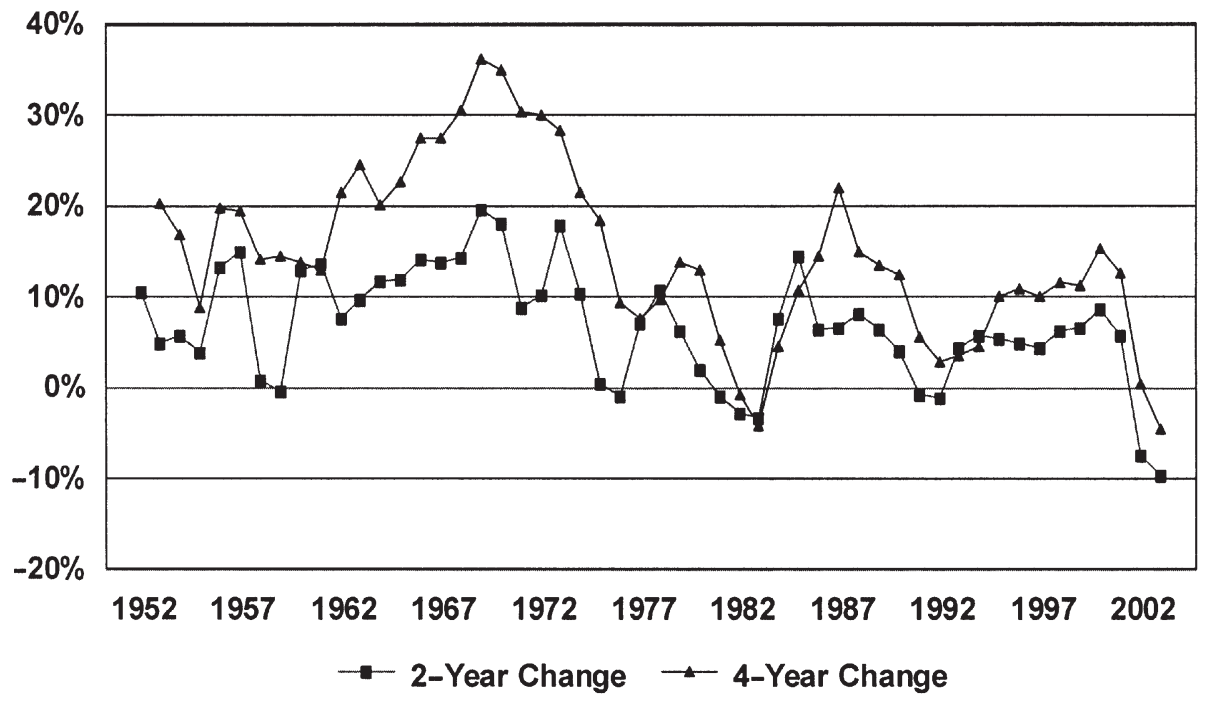


decrease. While the causes of the decline in revenues-in many states for a second straight year (fiscal 2003)-are not fully understood, part of the reductions are the result of the major decline in financial asset values that continued during calendar 2002 after the recession had technically ended. It may also have resulted because income declines were disproportionately large for very high income taxpayers (with reductions in bonuses and stock options). To the extent that state income taxes are progressive, such changes have a larger impact on tax revenues.

Part of the perception about rapid revenue growth in the 1990s may have been generated by other factors. In addition to fairly rapid growth, states were experiencing windfall revenue gains and windfall surpluses. The unexpected gains occurred because state revenue growth was systematically underestimated each year during this period as was the case with federal revenues. The tobacco settlement funds also added to the state revenues. In addition, expenditure demands were less pressing as compared to prior experience. For example, medical care inflation abated during the latter part of the 1990s. States with their heavy Medicaid burdens had become accustomed to double-digit cost increases and were pleasantly surprised when costs went up less steeply. Welfare roles also declined during the post-1996 welfare reform period. Even the cost of pensions became less onerous because the rapid increase in equity values had a dramatic impact on pension fund assets, thus reducing pension funding obligations. Some states were able to reduce or eliminate pension fund contributions during this period because stock market gains took care of their obligations. Together the unexpected revenue growth along with a surprising moderation in expenditure demands created what one might call a golden era for state finance.

In summary, the descriptive results suggest a decline in state revenues after the 2001 recession that is unmatched in the last 50 years. Further, the decline is not the result of an anomalous pre-recession revenue growth that led to the ultimate decline.

\section{Analytical Results}

In this section, we employ a time-series econometric model to explain state revenue performance. Our dependent variable is the annual change in real per capita state tax revenue. Our three explanatory variables are the annual change in real per capita income, the percentage of state tax revenue from the individual income tax, and the annual percentage change in the Dow Jones Industrial Average (DJIA). The results are presented in Table 2.

TABLE 2

PER CAPITA CHANGE IN REAL STATE TAX REVENUES

\begin{tabular}{lccc}
\hline Variable & Model 1A & Model 1B & Model 1C \\
\hline Percentage change in real income & 1.058352 & 1.000859 & 1.093540 \\
& $(5.62)$ & $(5.65)$ & $(6.26)$ \\
Percentage of revenue from income tax & & -0.130401 & -0.132612 \\
& & $(-2.86)$ & 0.058754 \\
Percentage change in DJIA & & $(2.27)$ \\
& & 0.030134 & 0.022914 \\
Constant & -0.002573 & $(2.24)$ & $(1.73)$ \\
& $(-0.34)$ & 0.48 & 0.53 \\
R-square & 0.39 & t-values in parentheses \\
\hline
\end{tabular}


Model 1A estimates revenue changes based solely on income changes, Model 1B is based on income changes and income tax reliance, and Model $1 \mathrm{C}$ employs all three explanatory variables. The variables are significant in each of the formulations. The models explain from 39 to 53 percent of the variation. The change in income variable is highly significant in all three models. Both change of income and change in the DJIA have the expected sign. The income tax reliance variable has a negative sign suggesting that increased reliance on the income tax provides stability (i. e., reduces the expected change in tax revenues), a seemingly counterintuitive result. An alternative explanation is that the income tax reliance variable may be serving as a proxy for time since reliance increased fairly steadily over the period of the analysis while overall volatility declined.

The inflation rate was also included as an explanatory variable, but it did not prove significant and did not add to the explanatory power of the analysis. Since the analysis is conducted using real values, the direct impact of the inflation rate is accounted for. However, the tax system could have non-neutralities with respect to inflation such as "bracket creep" for the income tax or the erosion of revenues for specific excise taxes such as those imposed on gasoline, alcohol, and tobacco. These effects do not appear to have been significant. $^{8}$

The results of the estimates were used to produce residuals for each year for each equation. These results are presented in Figure 4, Panels 1, 2, \& 3 . The residuals suggest that the explanatory variables do not fully explain the decrease in revenue after the 2001 recession. The results indicate that revenues behaved in a very unusual manner during and after the 2001 recession. The residuals can be thought of as revenue shortfalls that state experienced compared to reasonable expectations. The negative residuals for 2002 are the largest of any of the 51 years in the series. The residuals for 2001 and 2003 are also very large and negative. This is true for all three formulations.

A similar phenomenon occurred at the federal level where there was an unexpected and largely unexplained reduction in federal tax revenues. ${ }^{9}$ The revenue decline after the 2001 recession is at least a "50-year" flood, a virtually one-of-a-kind event. In a sense, the unexpected and not fully explained decline in revenues after the 2001 recession is a kind of apology for state fiscal behavior. It may explain why states were not better prepared for the downturn and why their initial responses to the problems were often weak given the magnitude of the problem.

Except for 2000, these results also confirm the observation that the revenue growth in the years leading up to the 2001 recession was not unusually strong. The residuals in all three specifications from 1996 to 1999 were either negative or very small positive values. The implications of these results for state budget policy are explored below.

\section{STATE-LEVEL REVENUE RESULTS}

The analysis of state tax revenues in aggregate may mask variations in revenue

\footnotetext{
${ }^{8}$ On the expenditure side of the fiscal equation, high inflation rates may ease some budget problems. For example, it is much easier for a state to provide nominal wage and salary increases several percentage points below the inflation rate in a high-inflation environment. This is not possible when the inflation rate is near zero.

9 In this regard, the 2003 Economic Report of the President states, "The decline in receipts during the most recent downturn in the business cycle has been especially pronounced. Total receipts in fiscal 2002 were $\$ 1,853$ billion, having fallen $\$ 138$ billion, or about 7 percent, from their level in fiscal 2001. This represented a much larger percentage decrease in receipts than in previous, far more severe recessions. ... More detailed information on the precise sources of the decline in receipts will not be available until the Treasury completes its regular annual examination of individual tax returns."
} 
Figure 4. Unexplained Variations in Real Per Capita State Tax Revenues
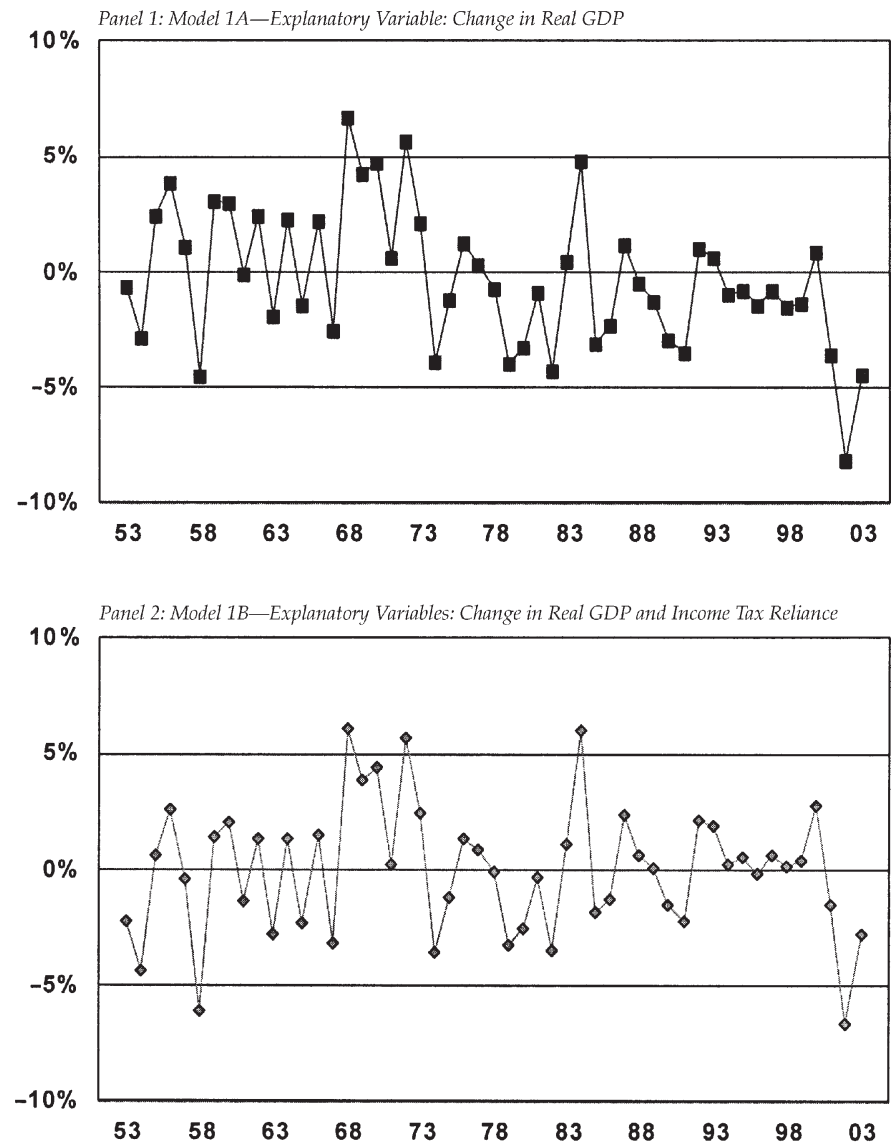

Panel 3: Model 1B-Eplanatory Variables: Change in Real GDP, Income Tax Reliance,

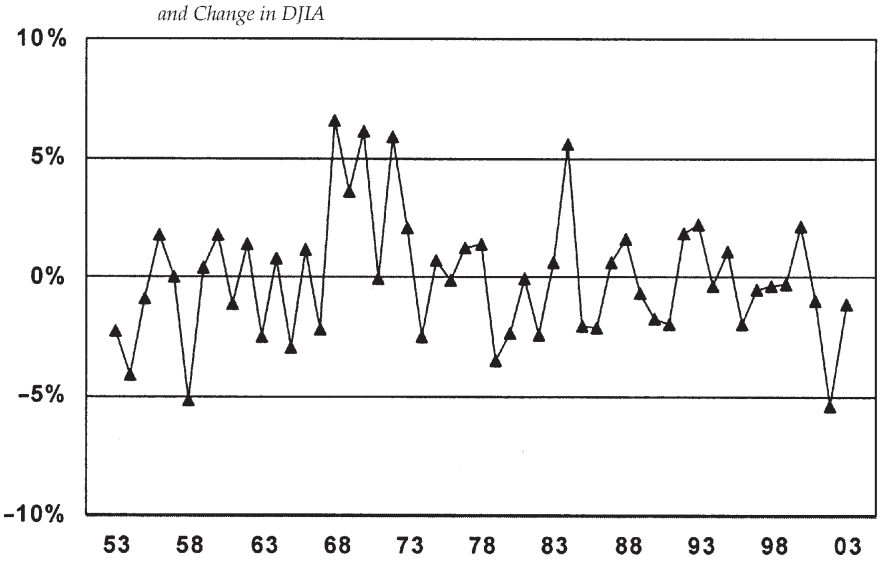


performance among the states. In this section, we conduct a similar analysis to that in the preceding section, but based on state-level revenues spanning from 1977 to $2002 .{ }^{10}$ Figure 5 presents information about the nominal change in tax revenue for 2002 over 2001. Thirty-nine states suffered nominal declines in revenue. Fiscal 2002 was the worst real revenue performance for 28 states for the 1977-2002 period-the result of the combination of a real decline and a historically low rate of inflation. The poor performance in the early 1980s was masked by high inflation.

Table 3 and Figure 6 present similar information in real terms. Forty-two of the 50 states suffered real declines in revenue. Seven states had double digit declines including California's 15 percent. However, 2002, while still the worst year since 1977 in real terms for a plurality of states, does not appear as bad in relative terms. (See Figure 7.) The years 1981 and
1982 were also very bad for a number of states, especially in the Midwest which suffered the brunt of the 1980 and 1981 recessions.

Tax revenue performance by region for 2001 and 2002 is presented in Figure 8. The results show that revenue problems arrived early (2001) in the Great Lakes and were extremely severe in the Far West (with California, Alaska, and Oregon being three of the four worst performing states) and New England in 2002.

To determine how states performed relative to expectations, we carry out an analysis related to the work above, but using panel data from the 50 states. (See the Appendix for a fuller description of the approach.) The results presented here are based on a model that includes only state personal income and state fixed effects as the explanatory variables. ${ }^{11}$

The difference between the actual and predicted tax revenues is derived for each state and each year. ${ }^{12}$ To normalize this

Figure 5. Percentage Change in Nominal State Tax Revenues: 2002

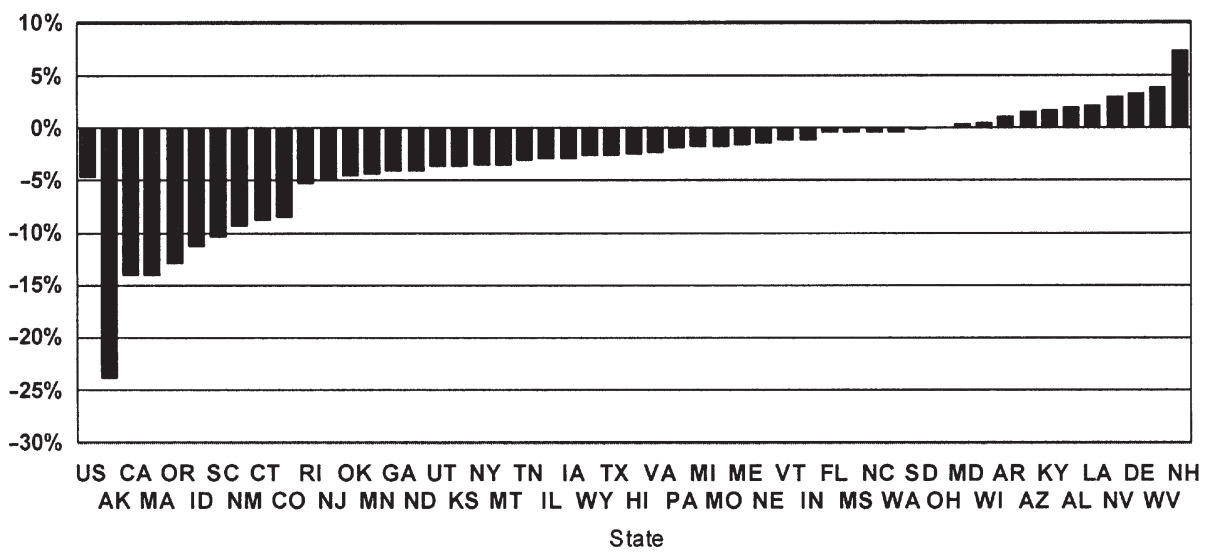

10 The data include both the impacts of the economy as well as "enacted changes." Overall, the impact of enacted changes was very small in recent years. See footnote 3 and Maag and Merriman (2003). However, the impacts of enacted changes may be more substantial for particular states.

11 We also explored other specifications that included information on state employment and states' reliance on the personal income tax. Results from these specifications were very similar to those from the model that only included personal income.

12 An alternative way of addressing underperformance would have been to include a year dummy in the analysis. When this was done, the size of the 2002 dummy was strongly negative for almost all states. 
TABLE 3

\% CHANGE IN REAL STATE TAX REVENUES: 2002

\begin{tabular}{rlrllr}
\hline 1 & Alaska & -24.6 & 26 & Virginia & -3.4 \\
2 & California & -15.0 & 27 & Pennsylvania & -3.0 \\
3 & Massachusetts & -14.9 & 28 & Michigan & -2.9 \\
4 & Oregon & -13.8 & 29 & Missouri & -2.9 \\
5 & Idaho & -12.2 & 30 & Maine & -2.7 \\
6 & South Carolina & -11.4 & 31 & Nebraska & -2.6 \\
7 & New Mexico & -10.4 & 32 & Vermont & -2.3 \\
8 & Connecticut & -9.7 & 33 & Indiana & -2.3 \\
9 & Colorado & -9.5 & 34 & Florida & -1.6 \\
10 & Rhode Island & -6.4 & 35 & Mississippi & -1.5 \\
11 & New Jersey & -5.9 & 36 & North Carolina & -1.5 \\
& U.S. & -5.8 & 37 & Washington & -1.5 \\
12 & Oklahoma & -5.6 & 38 & South Dakota & -1.2 \\
13 & Minnesota & -5.5 & 39 & Ohio & -1.1 \\
14 & Georgia & -5.2 & 40 & Maryland & -0.8 \\
15 & North Dakota & -5.1 & 41 & Wisconsin & -0.7 \\
16 & Utah & -4.7 & 42 & Arkansas & -0.2 \\
17 & Kansas & -4.7 & 43 & Arizona & 0.3 \\
18 & New York & -4.6 & 44 & Kentucky & 0.4 \\
19 & Montana & -4.6 & 45 & Alabama & 0.8 \\
20 & Tennessee & -4.1 & 46 & Louisiana & 0.9 \\
21 & Illinois & -4.1 & 47 & Nevada & 1.8 \\
22 & Iowa & -4.0 & 48 & Delaware & 2.1 \\
23 & Wyoming & -3.7 & 49 & West Virginia & 2.6 \\
24 & Texas & -3.7 & 50 & New Hampshire & 6.1 \\
25 & Hawaii & -3.6 & & & \\
\hline
\end{tabular}

Figure 6. Percentage Change in Real State Tax Revenues: 2002

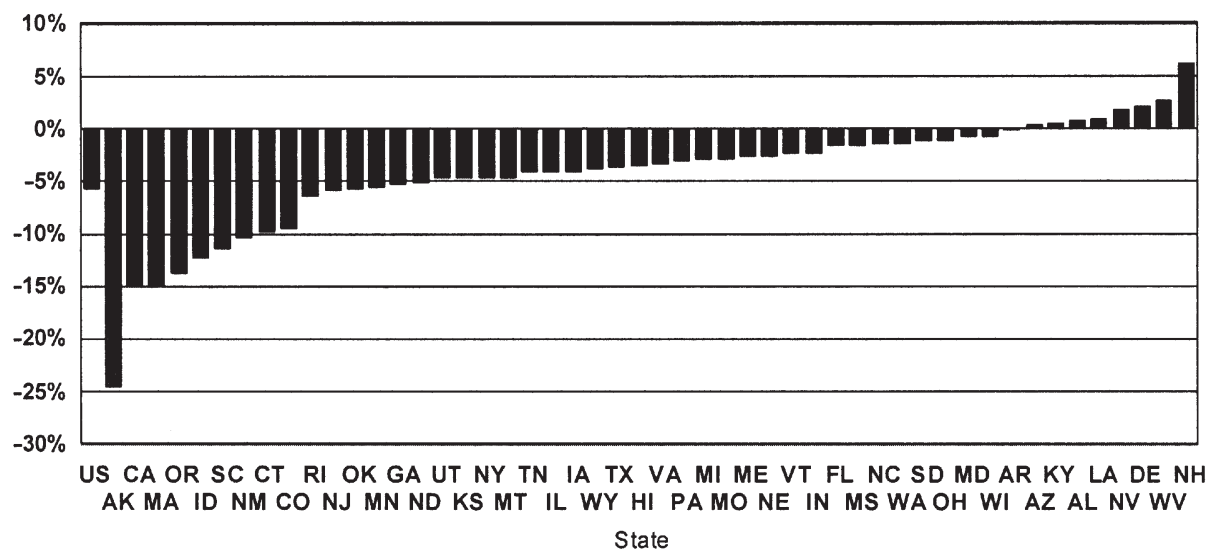

residual, it is divided by the actual state revenue. Figure 9 presents the results of this analysis of underperformance. The results are similar, but not identical to those presented earlier with Alaska, California, and Oregon faring very poorly. Tax revenues in 48 of the 50 states underperformed in 2002 in the sense that actual revenues fell short of predicted levels that included the impacts of changes in state personal income.

Figure 10 shows that 2002 was the worst year for underperformance in 14 states during the 1977-2002 period, more states than in any other year. However, a number of states experienced their worst years in the recessions of 1980 and 1981. 
Figure 7. Year of Worst Real Revenue Performance

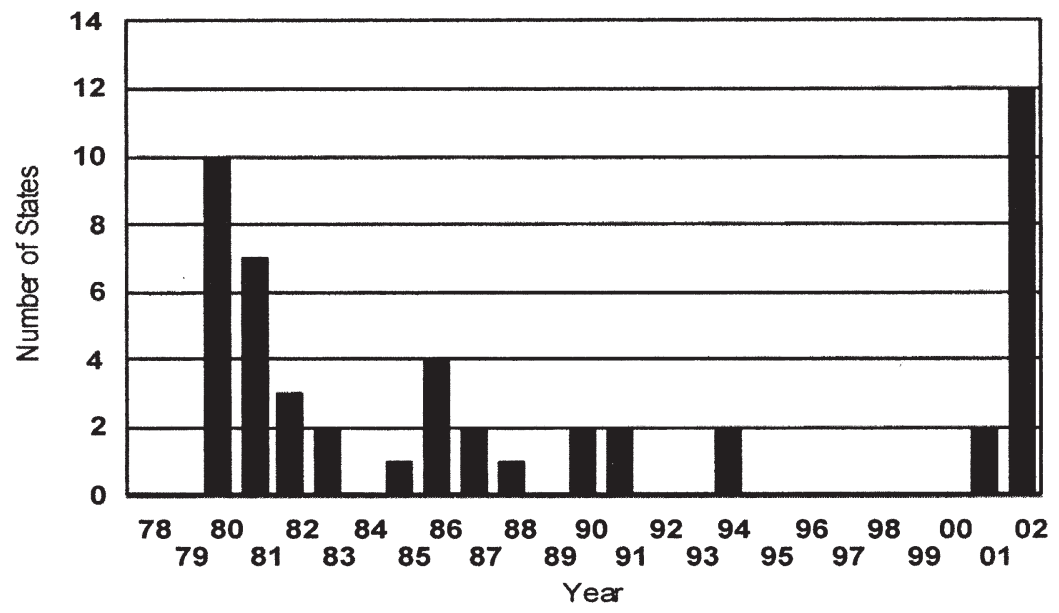

Figure 8. Tax Revenue Performance by Region: 2001 and 2002

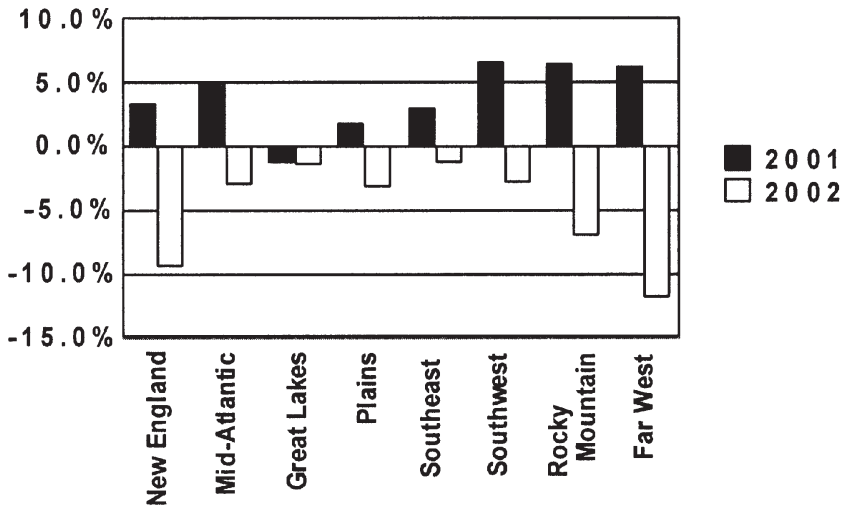

Figure 9. Underperformance of Revenue (Residuals as Percentage of Actual): 2002

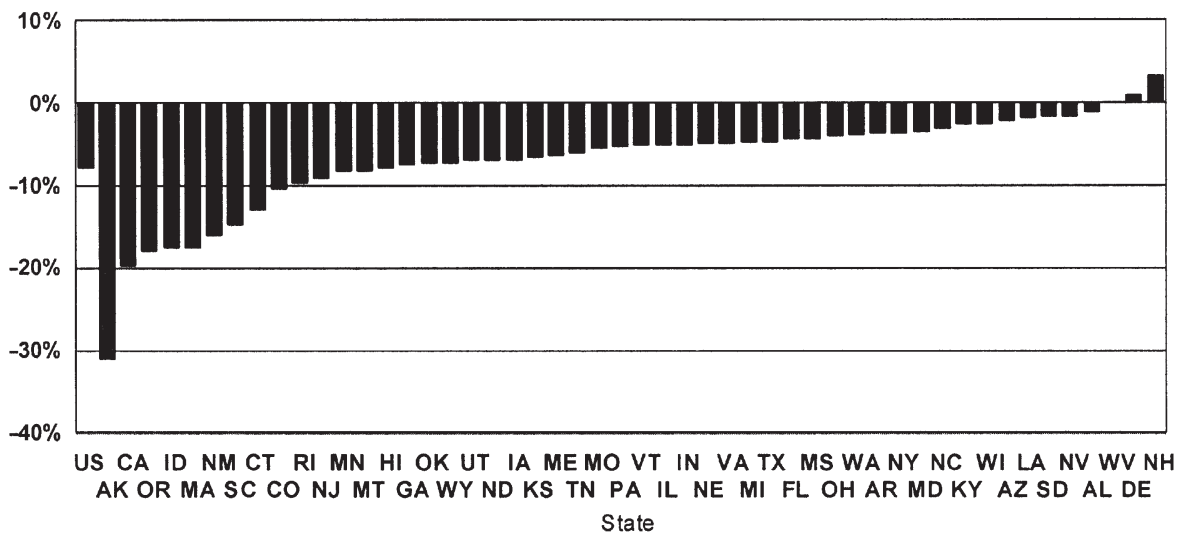


Figure 10. Year of Worst Underperformance of Revenue

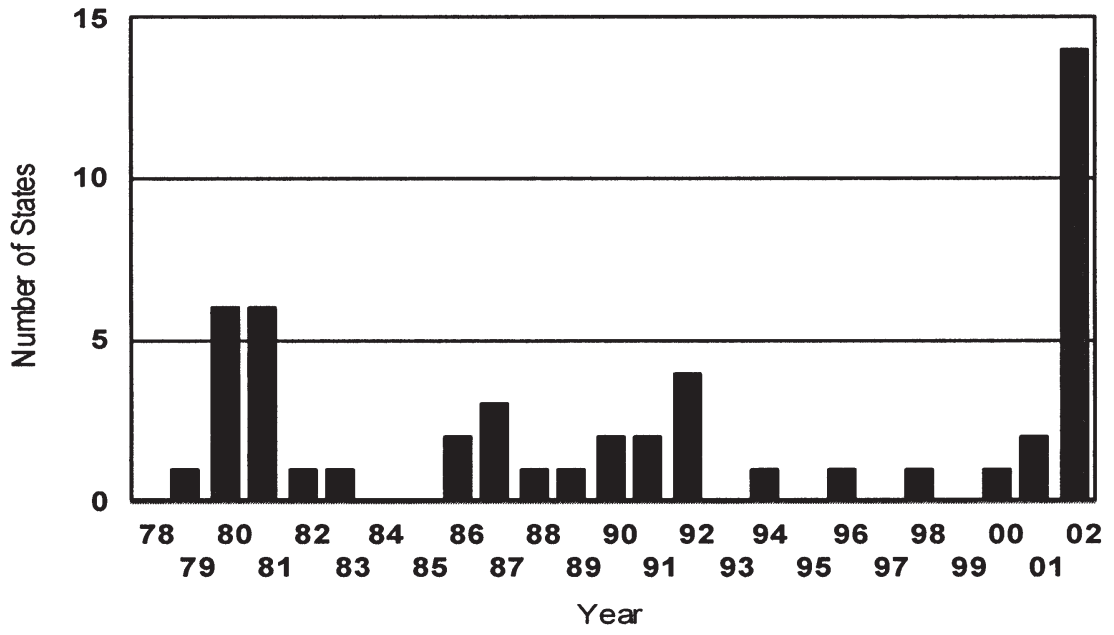

The various panels of Figure 11 present information about underperformance for a number of key states. ${ }^{13}$ California is presented because of its importance as the most populace state and the one with a large and highly visible fiscal problem. The analysis certainly confirms the prominent role that the state of California has played in the state fiscal crisis debate. ${ }^{14}$ Colorado has sometimes been put forward as an example of fiscal prudence stemming from its state-level spending limits. The results here, though, show that spending limits do not protect states against revenue declines and underperformance.

Illinois and Michigan both experienced underperformance in 2001 as well as 2002. Both states experienced larger relative underperformance in the 1980 recession than in 2002. Massachusetts, like California, had a relative good performance in 2001 followed by a major decline in 2002. New York had a similar, but milder pattern of underperformance. With neither a broad-based income tax nor a general sales tax, New Hampshire was one of the few states that avoided most of the fiscal pain of the downturn.

In this section, we focused on the performance of state-level tax revenues. Underperformance of revenues is not necessarily a measure of fiscal crisis, but it suggests the magnitude of the problems that must be addressed. The use of budget reserves, expenditure reductions, and tax increases can all be used to address the problems generated by revenue shortfalls.

\section{AN EVALUATION OF STRATEGIES TO PREPARE FOR THE DOWNTURN}

We address here the question of how states could have prepared for the downturn. We use a stylized simulation of state revenue and expenditure growth that incorporates reasonable assumptions about revenue growth over the period from 1993 to 2003. Much of the debate centers on what the states could have done prior to

\footnotetext{
13 Alaska, the worst performing state, is not included because of the unusual nature of its revenues system with the heavy reliance on natural resource revenues.

${ }_{14}$ Despite California's large size and serious revenue problems, the state does not drive the national results. The estimates were carried out with and without the state of California. We produced estimates that indicate that the overall state revenue pattern does not change substantially when California data are excluded.
} 
Figure 11. Revenue Underperformance in Selected States (Residuals as Percentage of Actual)

U.S.

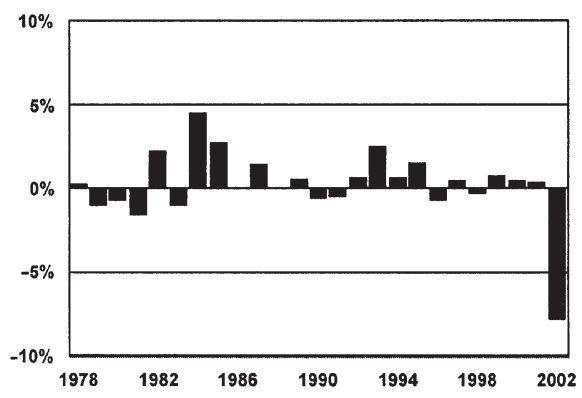

California
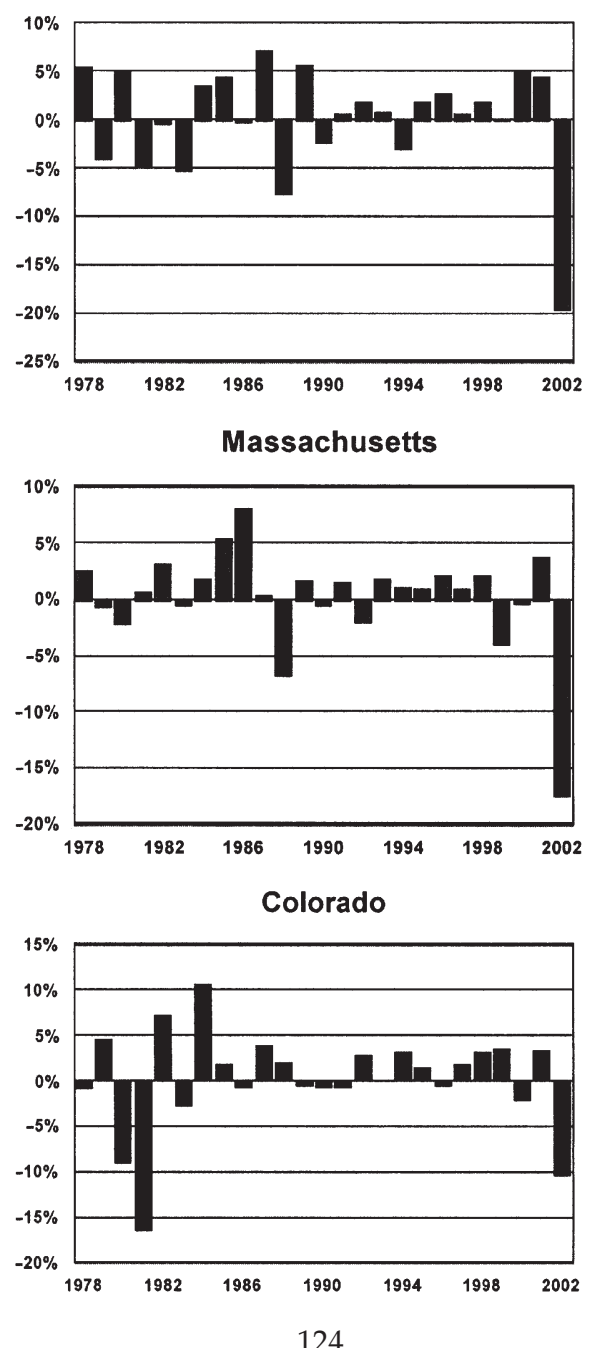
Figure 11 (continued). Revenue Underperformance in Selected States (Residuals as Percentage of Actual)

Illinois

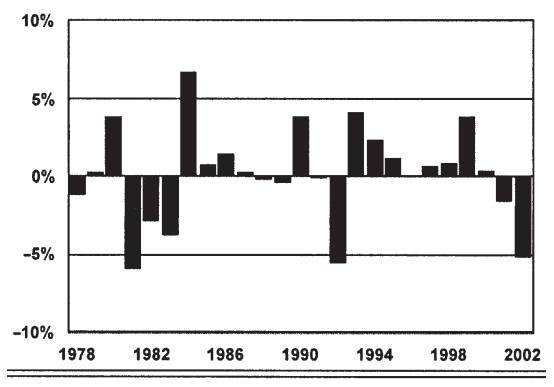

Michigan

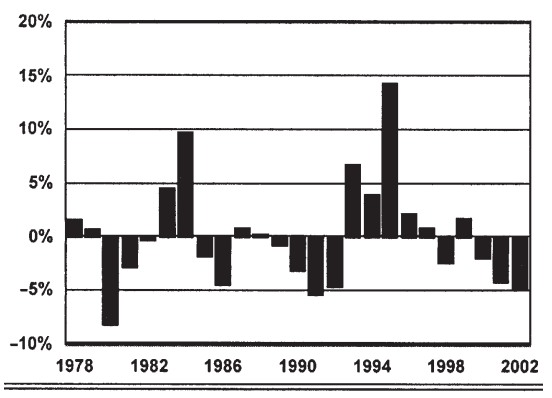

New Hampshire

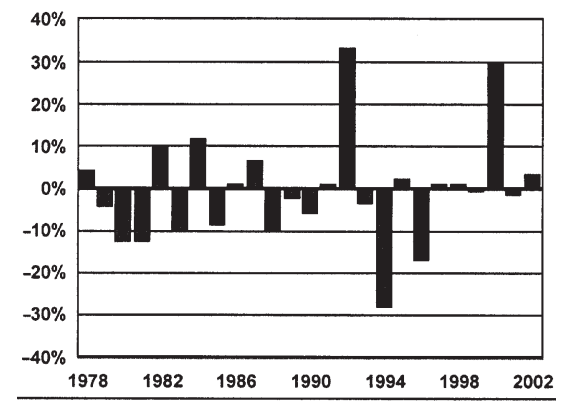

New York

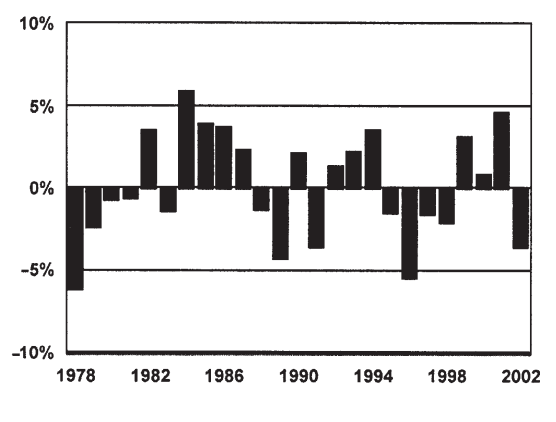


the recession to avoid the problems that occurred in 2002 and after. The debate has focused on the possible use of relatively inflexible taxing, spending, and/or saving rules that could be put in place to avoid problems. These place a premium on the avoidance of discretionary tax and expenditure changes to address the problem. The stated goal of most proponents of budget rules is to provide fiscal stability and discipline over the business cycle. However, it is suggested below that a number of other goals also influence the choice of these rules.

A substantial body of technical literature addresses the issue of fixed rules versus discretion in intertemporal consumption-saving decisionmaking. ${ }^{15}$ Much of this analysis applies to fiscal choices as well. The use of commitment strategies such as balanced budget rules, mandatory rainy day funds, and tax and/or expenditure growth limits are often proposed by both liberals and conservatives to improve fiscal discipline. Obviously, each interest group wants a commitment rule that favors its particular interests. Fixed rules may be even more important for governments as opposed to individuals because such rules may limit rent-seeking behavior in the fight over fiscal spoils. On the other hand, rules that preserve discipline may also reduce flexibility to make adjustments resulting from shocks or new information. The trade-off between the two and the question of when to depart from predetermined rules is the key issue.

A series of simulations (in real terms) are presented for the period 1994 until 2003. It is assumed that revenues equal expenditures in 1993 (after the recovery from the 1990 recession) and that there are no excess reserves at that date. In each simulation, revenues are assumed to grow at the lesser of the actual rate of increase or at the limit set by particular budget rules. Expenditures grow at a predetermined rate according to the decision rule in place. The simulations are used to examine four different scenarios: ${ }^{16}$

1. The "What, me worry?" option where expenditures are allowed to grow at the same rate (3.95 percent) as revenues grew from 1993 to 2001.

2. A cyclically-balanced budget where revenues are equal to expenditures over the 1993 to 2003 period. This would entail expenditure growth of 3.6 percent per year.

3. A constrained revenue growth scenario where expenditures are allowed to grow at the rate $(2.3$ percent) that revenues grew from 1993 to 2003, two years beyond the period in scenario 1 . Under this scenario, taxes are not permanently reduced even though expenditures are restrained.

4. A permanent tax cut scenario where revenue increases are limited to the lesser of two percent or the actual increase. When tax revenues are poised to increase by more than two percent, taxes are permanently cut to limit the increase to two percent.

The "What, me worry?" strategy is, in a sense, a straw man where state governments spend all of their tax revenue on recurring expenditures during the expansion. No surpluses are generated during good times to offset future downturns. While this is an extreme example, it approximates the behavior of a number of states. Simulation 1 (Figure 12) illustrates the results of this strategy where revenues and expenditures are in rough balance

\footnotetext{
15 This is summarized in Amador, Werning, and Angeletos (2003).

${ }_{16}$ All of these scenarios assume of a level of knowledge about future revenue growth that is not available to actual decision makers.
} 
Figure 12. Simulation 1: “What, me worry?" Scenario
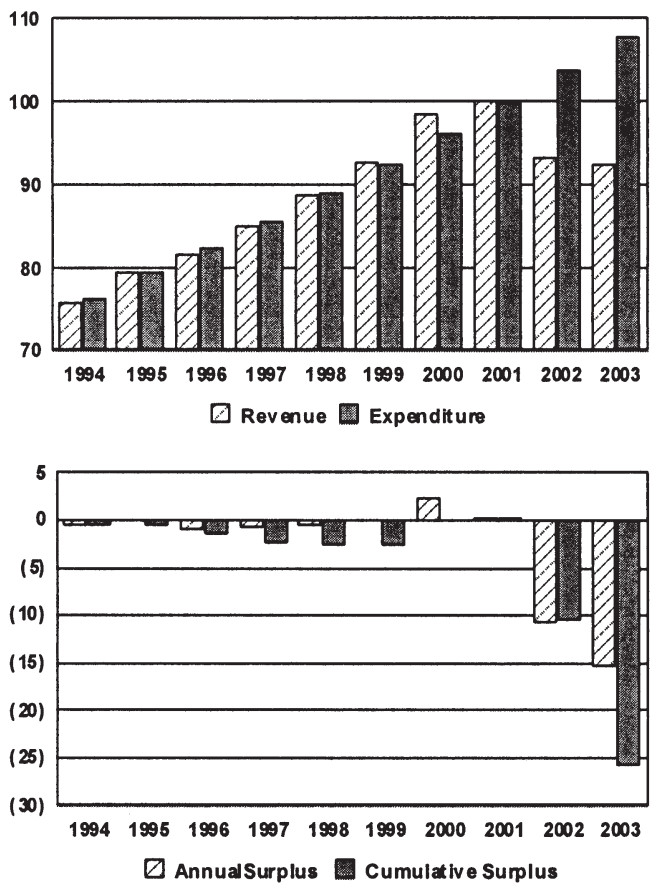

Assumptions: 2001 Revenue $=100$; Revenue Growth $=$ Actual Expenditure Growth = Growth 3.95\% (same as revenue growth from (1993-2001)

until the bottom drops out in 2002 when a massive deficit results with even worse problems in 2003. The top panel of each simulation shows the yearly revenues and expenditures while the lower panel displays the annual surplus (deficit) and the cumulative surpluses (deficits).

In this simulation, the 2002 and 2003 results are unsustainable, and thus discretionary changes (increased taxes and/or decreased spending) would have to be implemented. Obviously this rule will not fulfill the goal of avoiding the need for discretionary changes.

Simulation 2 (Figure 13) implements a cyclically-balanced budget over the 1993-2002 period. Surpluses are generated during the period from 1994 to 2001 to offset the shortfall during the recession. This supports a consistent growth in gov- ernment spending that is not impacted by the cycle. The problem with this scenario is that the world does not end in 2003. Even though the budget is balanced over the period from 1993 to 2003, the existing revenue structure for 2004 and future years will fall far short (in the 10 percent range) of covering expenditure demands even assuming a resumption of normal economic growth. The precipitous reduction in revenues in 2002 with no recovery in 2003 results in a ratcheting down of the revenue baseline so that it will no longer support the predetermined expenditure path, necessitating discretionary tax or spending changes to put the state back on track.

The practices in most states during the expansion of the 1990s were a hybrid of scenarios 1 and 2. States did not spend 
Figure 13. Simulation 2: Cyclically Balanced Budget Scenario
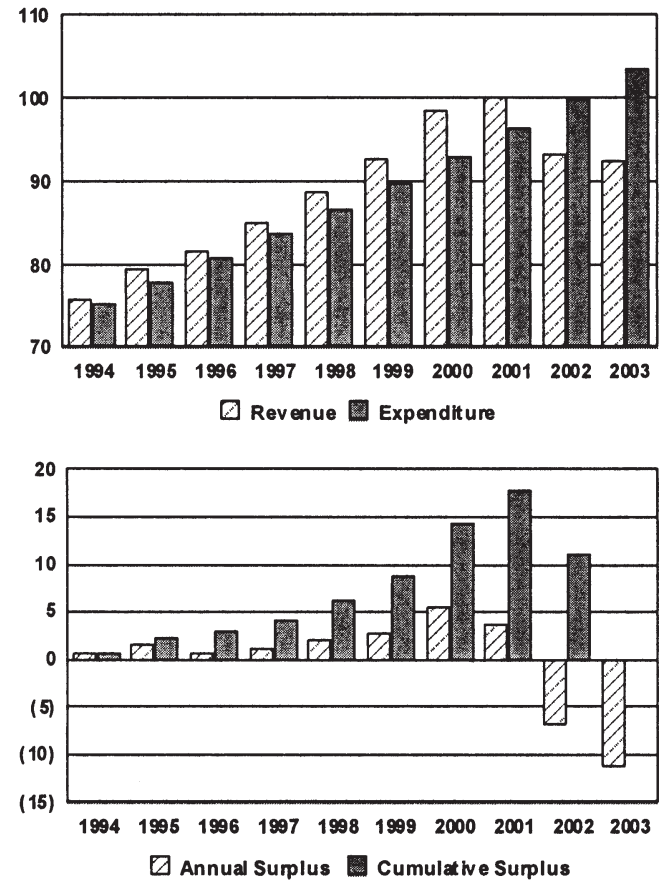

Assumptions: 2001 Revenue $=100$; Revenue Growth $=$ Actual Expenditure Growth $=$ Growth $3.60 \%$

every penny of increasing revenues, but they also fell short of accumulating reserves sufficient for a cyclically-balanced budget. Clearly the cyclically-balanced budget approach is a much more stable rule than scenario 1 , but is does not avoid the need for discretionary changes.

The constrained expenditure growth scenario is the only one that could provide stability over the cyclic, but it would come at the cost of greatly repressed spending. In Simulation 3 (Figure 14), annual spending would be limited to the growth rate of revenues from 1993 to 2003 (2.3 percent) even though actual revenue growth would far exceed expenditure growth in many years. This extra revenue could not be returned to the taxpayers in terms of permanent tax cuts, but it could be used for one-time spending programs (such as debt retirement) or one-time tax cuts. This would maintain the tax base while not expanding the spending base. This would be a substantial political challenge in most states. In 2003, actual revenues would match the expenditures although expenditures would be more than 10 percent below the balanced budget scenario.

The final scenario (Simulation 4 shown in Figure 15) involves making permanent tax cuts to dissipate rapidly expanding revenues. Here expenditures are allowed to grow at only two percent while any revenue increases over two percent trigger permanent tax cuts to hold revenue growth to the same pace. This approach would indeed keep expenditures under control, but it would not protect against economic downturns. Under this scenario, the economic downturn in 2002 would reduce revenues by the same percentage (on a smaller base) as in the other 
Figure 14. Simulation 3: Constrained Expenditure Growth Scenario
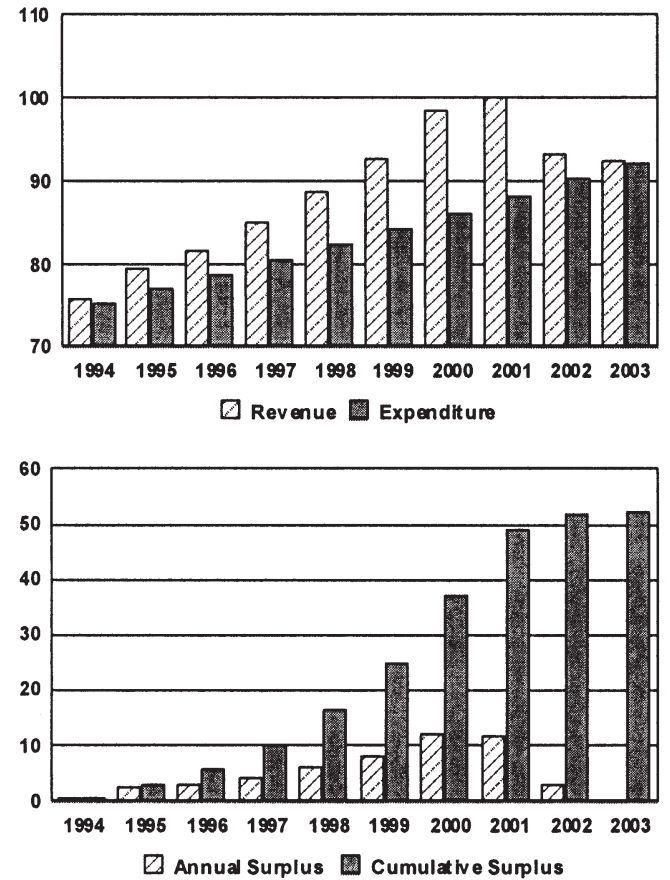

Assumptions: 2001 Revenue $=100$; Revenue Growth $=$ Actual Expenditure Growth $=$ Growth $2.30 \%$ (same as revenue growth from 1993-2003)

scenarios and create shortfalls as large (as a percentage of revenues) as the other approaches. Note the results for Colorado presented earlier. Colorado has what appear to be effective controls on expenditure growth, but this did not protect the state against major revenue reductions in 2002. Colorado ranked ninth in terms of the largest fall in real revenues and in terms of underperformance in 2002. This strategy may be a way of controlling the growth of government, but it does not provide stability over the cycle.

\section{CONCLUDING REMARKS}

States have been roundly criticized from both the left and right for their handling of the pre-recession growth period of the late 1990s. Conservatives have argued that budget restraint and tax cuts during this expansion phase could have avoided most of the pain of the downturn. Liberals have faulted the states for not finding ways, such as the creation of large rainy-day fund balances, to protect key spending programs in the downturn.

In the analysis presented here, we suggest that neither of these views is correct. First, the downturn after 2001 was clearly a one-of-a-kind phenomenon in its impact on state government tax revenues. The absolute decline in revenues was unprecedented and the decline was disproportionately large compared to the size of the economic downturn. Budget officers and politicians cannot be reasonably faulted for being unprepared for the decline in revenues that occurred in 2002 and 2003. 
Figure 15. Simulation 4: Permanent Tax Cuts Scenario
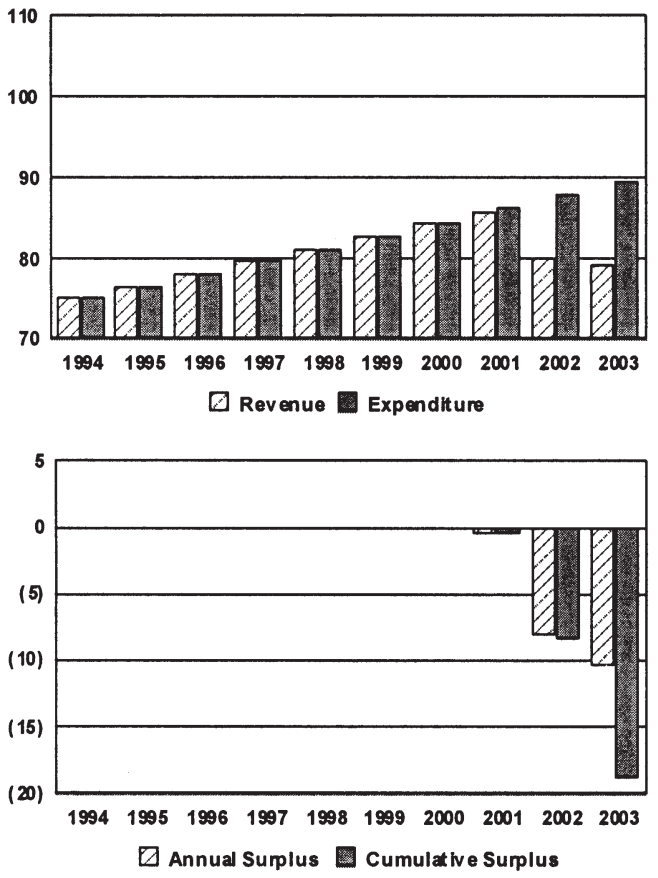

Assumptions: 2001 Revenue $=100$; Revenue Growth $=$ Lesser of Actual or $2 \%$ Expenditure Growth = Growth $2.0 \%$

Further, even if the dimensions of the downturn had been foreseen, it is unlikely that the commonly proposed strategies would have been effective in avoiding the need for major discretionary corrective measures to deal with fiscal problems in most states. In an average state, a rainyday fund of five percent of revenues at the beginning of 2002 would have been dissipated the first year of the downturn leaving a huge gap between actual revenues and desired spending for 2003 and future years. Similarly, permanent tax cuts enacted during the expansion of the late 1990s would have lowered the tax base, but it would not have protected this lower base from the precipitous revenue declines after 2001, leaving a huge revenue shortfall.

Even infusions of temporary federal aid as advocated by some analysts would have been inadequate as well. The problem that began after 2001 should be thought of not as the usual cyclical decline in revenues followed by a gradual recovery to pre-recession levels. Instead, it is more of a one-time, permanent ratcheting down of revenues to a lower base from which future revenues will grow. Economic growth is unlikely to ever return revenues to the old growth path. In such a case, it is necessary to make permanent structural adjustments to revenues or expenditures to bring them into balance again. No automatic budget rule is likely to do this.

Obviously, rainy day funds, federal aid, and the like are extremely valuable tools during a downturn. However, in a major disruption, they should not be viewed as mechanisms for avoiding painful choices, but as tools for making adjustments more manageable. It appears, however, that in many states the use of reserve funds as 
well as temporary expedients such as the sale of assets and borrowing to fund current expenditures have been employed not to smooth the transition to a new long run equilibrium, but, instead, to put off the day of reckoning when the hard choices have to be made (see Maag and Merriman (2003)).

It should also be noted that the wellknown problems with the structure of state tax systems, such as the failure to tax services under the sales tax, problems taxing e-commerce, and the shrinking of the corporate base, were not the cause of the states' recent problems. In fact, many of longstanding proposals for state tax reform would have had little impact on protecting states from the consequences of the recent downturn and, in some cases, may have actually made matters worse. For example, one of the goals of state tax reform has been to make tax revenues more responsive to economic growth to keep pace better with the rate of growth of expenditure demands. Increasing the progressivity of the income tax and the inclusion of services in the sales tax base are examples of such policies. ${ }^{17}$ While these may be worthy ideas, had such changes been in place the problems of the downturn would very likely have been more, not less severe. States also are searching for ways to reverse the erosion of the corporate income tax base. However, a greater reliance on the corporate income tax increases the volatility of state tax systems and would have worsened the fiscal problems of the states during the recent downturn. Finally, the longstanding movement away from local property taxes to state-level taxes accentuated the problems of state and local governments since the property tax weathered the recession much better than the income and sales taxes. ${ }^{18}$

Why is such importance placed on inflexible budget rules by both liberals and conservatives? The ostensive goal of both is to provide fiscal stability over the business cycle. However, these rules may also be vehicles to pursue other goals. For example, the prime purpose of expenditure growth limitations for conservatives is not to provide stability, but to reduce the relative size of government. Similarly, rules that funnel revenues into budget stabilization funds also may be a way of protecting the tax base against permanent tax cuts during expansions. Even proponents of temporary federal aid to states may be primarily interested in the macro goal of neutralizing the potentially pro-cyclical impacts of state tax increases or expenditure cuts, and not the goal of state budget stability.

In summary, the size and unusual nature of the recent downturn in state revenues will require major discretionary structural changes in state revenues and expenditures to bring states back into fiscal balance. Reactive policies that may have been effective in the past, such as waiting for economic growth to solve the problems, will not be sufficient.

\section{REFERENCES}

Amador, Manuel, Ivan Werning, and

George-Marios-Angeltos.

"Commitment vs. Flexibility." MIT Working Paper. Boston, MA: Massachsetts Institute of Technology, 2003. http:/ / papers.ssrn.com/ sol3 / papers.cfm?abstract_id=471822.

\footnotetext{
17 While these reform measures would not have helped states avoid their recent problems, they could be a way of closing the gap that emerged during the recession between expenditure demands and continuing revenue. For example, taxing services would provide an immediate increase in the sales tax base as well as contribute to higher growth in the long run. Finding a way of enforcing sales and use taxes on Internet sales would have a similar impact.

18 As noted above, property tax revenues actually increased during the recession-in real terms by 3.1 percent in 2001 and 7.6 percent in 2002. This was likely the result of assessment increases as well as rate increases to offset reductions in state aid to local governments.
} 
Daly, Mary.

"Understanding State Budget Trouble." FRBSF Economic Letter No. 2003-23. San Francisco, CA: The Federal Reserve Bank of San Francisco, August 15, 2003.

Economic Report of the President.

February, 2003: 54. http://w3.access.gpo. gov/eop/.

Garret, Thomas A.

"State Budget Crises: Cause and Effect." National Economic Trends. St. Louis, MO: The Federal Reserve Bank of St. Louis, November 3, 2003.

Knight, Brian, Andrea Kusko, and Laura

Rubin.

"Problems and Prospects for State and Local Governments." In State Fiscal Crises: Causes, Consequences, Solutions. edited by Therese J. McGuire and C. Eugene Steurerle. State Tax Notes 30 No. 5 (November 2, 2003): 379-91. Maag, Elaine, and David Merriman.

"Tax Policy Responses to Revenue Shortfalls." In State Fiscal Crises: Causes, Consequences, Solutions, edited by Therese J. McGuire and C. Eugene Steurerle. State Tax Notes 30 No. 5 (November 2, 2003): 393-403.

National Governors Association and National Association of State Budget Officers.

The Fiscal Survey of the States. Washington, D.C., June, 2003. http:/ / www.nasbo. org / Publications / fiscalsurvey / fsspring20030813.pdf.

Poterba, James M.

"State Responses to Fiscal Crises: The Effects of Budgetary Institutions and Politics." Journal of Political Economy 102 No. 4 (1994): 799-821.

The Wall Street Journal.

"States of Recovery." Editorial. (December 3, 2003): A16.

\section{APPENDIX}

The state-level data on revenue are from the Census Bureau and cover years 1977 through 2002. Annual data for state personal income are from the Bureau of Economic Analysis and cover the same period. The following equation relates total annual state taxes to state personal income and state fixed effects:

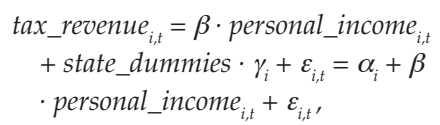

where $i$ denotes the state and $t$ the year of the observation. Thus, tax_revenue ${ }_{i t}$ represents total taxes for state $i$ in year $t$.

Because tax revenue and personal income are nonstationary (i.e., means and variances are not constant over time), logged differences (i.e., growth rates) are estimated instead of levels. Thus, the estimating equation becomes:

$$
\begin{aligned}
& \text { rev_growth }{ }_{i, t}=\ln \left(\frac{\text { tax_revenue }_{i, t}}{\text { tax_revenue }_{i, t-1}}\right)=\beta \\
& \cdot \ln \left(\frac{\text { personal_inc }_{i, t}}{\text { personal_inc }_{i, t-1}}\right)+\text { state_dummies }_{i, t} \cdot \gamma_{i}+\varepsilon_{i, t} \cdot
\end{aligned}
$$

The estimated parameters are then used to generate predicted revenue growth rates for 1978 through 2002. Next, the predicted growth rates are used to calculate predicted state tax revenue, using actual tax revenue in 1977 as the base. Thus, for a given year, $\bar{t}$, state $i$ 's predicted tax revenue can be expressed such that,

tax_revenue $_{i, t}=\left[\prod_{t=1978}^{t=\bar{t}}\left(1+\right.\right.$ rev_growth $\left.\left.{ }_{i, t}\right)\right]$

- tax_revenue ${ }_{i, 1977}$. 